\title{
RATES OF DEPOSITION ON LATERAL MORAINE EMBANKMENTS, GLACIER DE TSIDJIORE NOUVE, VALAIS, SWITZERLAND
}

\author{
By R. J. Small, I. R. Beecroft, \\ (Department of Geography, University of Southampton, Southampton SO9 5AH, England) \\ and D. M. STIRLing
}

(Department of Civil Engineering, City University, Northampton Square, London EC1V 0HB, England)

ABstract. In the last decade deposition on lateral moraine embankments of glacier de Tsidjiore Nouve has been re-activated on a large scale. An attempt has been made to reconstruct, from the dimensions of the embankments, average rates of debris accumulation on the moraines during the Neoglacial period. These are compared with rates of deposition over the period 1977-82, calculated from detailed changes in moraine profiles (surveyed by ground-and air-based photogrammetry) and measured rates of ice-margin ablation. At present total output of sediment, by marginal deposition and transport by melt-water streams, from glacier de Tsidjiore Nouve is in the order of $6400-9500 \mathrm{~m}^{3} / \mathrm{a}$; this suggests the possibility of a high average erosion rate within the glacier catchment of $1.55-2.29 \mathrm{~mm} / \mathrm{a}$.

RÉsumé. Taux de dépôt sur les terrasses morainiques latérales, glacier de Tsidjiore Nouve, Valais, Suisse. Pendant la dernière décennie, le remblaiement sur les terrasses morainiques latérales du glacier de Tsidjiore Nouve a recommencé sur une grande échelle. Une tentative de reconstitution des taux moyens d'accumulation de débris sur les terrasses morainiques pendant la période néoglaciare a été faite. Ces taux sont comparés avec ceux de la période 1978-82, calculés à partir des changements détaillés des profils de la moraine (topographie par photogrammétrie terrestre et aérienne) ainsi que de l'ablation mesurée sur les bords du glacier. Actuellement l'apport total de

\section{INTRODUCTION}

In its lowermost section, from the base of the Pigne d'Arolla ice fall, glacier de Tsidjiore Nouve is confined between massive lateral moraine embankments (Fig. 1). These attain lengths of $2 \mathrm{~km}$ (along the northern glacier margin) and $1.2 \mathrm{~km}$ (along the southern), and - over much of their length - heights in excess of $60 \mathrm{~m}$. Although the embankment summits are marked by small nested ridges (Small, 1983), the lateral moraines are essentially single ridges, consisting of superimposed sediments built up in a series of Neoglacial advances (Röthlisberger and Schneebeli, 1979). Since 1971 a further re-advance of glacier de Tsidjiore Nouve has re-activated sedimentation on the embankments. With the advance the glacier surface has risen, and the ice margins have begun to override the moraine crests at a number of sites (mainly along the northern embankment) at which

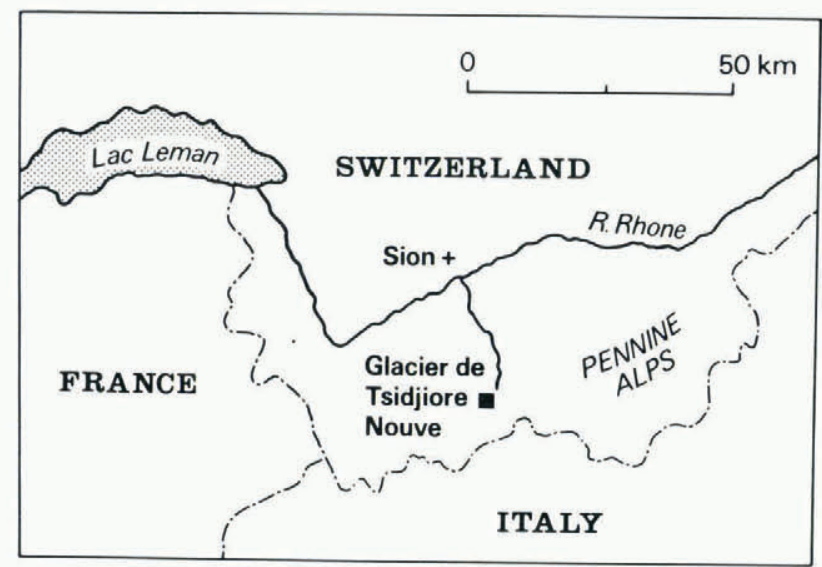

Fig. 1. Location of glacier de Tsidjiore Nowe. sédiments au glacier de Tsidjiore Nouve, à la fois par remblaiement latéral et transport par l'eau de fonte, est de l'ordre de $6400-9500 \mathrm{~m}^{3} \mathrm{a}^{-1}$; cec suggère la possibilité d'une vitesse d'érosion moyenne élevée dans le bassin versant de $1,55-2,99 \mathrm{~mm} \mathrm{a}^{-1}$.

Zusammenfassung. Ablagerungsraten an Seitenmoränenrücken des Glacier de Tsidjiore Nouve, Wallis, Schweiz. Im letzten Jahrzehnt hat sich die Ablagerung an den Seitenmoränenrücken des Glacier de Tsidjiore Nouve in hohem Masse Verstärkt. Es wurde versucht, die mittleren Raten der Schuttanhäufung an den Moränen während der neoglazialen Periode aus den Dimensionen der Rücken zu rekonstruieren. Diese lassen sich mit Ablagerungswerten über den Zeitraum 1977-82 vergleichen, die aus detaillierten Veränderungen von Moränenprofilen (vermessen mi terrestrischer und Luft-Photogrammetrie) und aus gemessenen Raten der Ablation am Eisrand berechnet wurden. Derzeit besitzt der gesamte Ausstoss an Sedimenten durch seitliche Ablagerung und Transport in Schmelzwasserströmen aus dem Glacier de Tsidjiore Nouve die Grössenordnung von $6400-9500 \mathrm{~m}^{3}$ pro Jahr; dies lässt auf die Möglichkeit einer hohen mittleren Erosionsrate innerhalb des Einzugsgebietes des Gletschers von 1,55-2,29 mm pro Jahr schliessen.

supraglacial and englacial debris is being dumped in considerable quantities (Whalley, 1973).

In simple terms, the recent depositional activity of glacier de Tsidjiore Nouve appears to have been as follows. When the glacier surface has been below the level of the embankments, little permanent marginal deposition has occurred; hence the development of very small nested moraines, as on the northern ridge. Instead, supraglacial debris (which occurs on this glacier in very large quantities) has been transported mainly to the snout and deposited in the proglacial zone. However, owing to the considerable fluctuations in the position of the snout during Neoglacial times, and the transportational activity of glacial melt-water streams, there is no large frontal moraine embankment. At times of glacial advance (as at present), when the glacier surface has risen above the level of the embankments, debris resting on the prominent supraglacial lateral moraines has been free to slide onto the embankment crests and distal slopes. There has been, additionally, some release of englacial debris (mainly concentrated in discrete marginal debris bands) from the exposed ice margins as these ablate back each summer. No evidence has been found of the transport of subglacial debris from the proximal to distal moraine faces, though it is possible that this may contribute to apparent moraine growth.

Observation shows that there is a simple annual rhythm to the depositional process (Fig. 2). Each summer the ice marginal faces, despite their "forward" motion, melt back by up to $5 \mathrm{~m}$; as a result undermined supraglacial, plus melted-out englacial, sediments slide onto the crest or proximal face of the embankment, building up a temporary debris ridge or a series of debris fans. In winter, with the cessation of ablation, the ice advances again onto the embankment summits, bulldozing the accumulated sediments onto the distal moraine slopes. Thereafter, until ablation has again caused ice-face recession, debris 


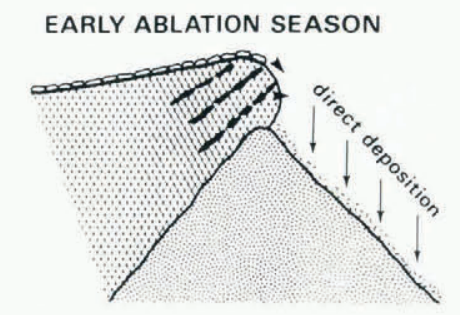

LATE ABLATION SEASON

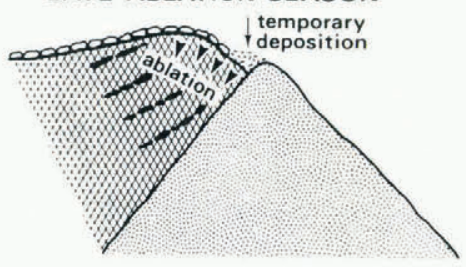

START OF SNOWMELT - following year

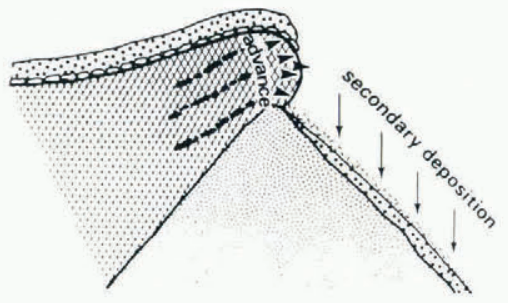

Fig. 2. Seasonal rhythm in the deposition of debris on the distal slope of a lateral moraine embankment. is shed directly onto the moraine outer face. The actual rates of annual accumulation should be susceptible of being gauged by the accurate reconstruction of successive moraine profiles.

\section{PAST RATES OF MORAINE ACCUMULATION}

Radiocarbon dating of fossil soils and preserved larch trunks indicates that the lateral moraine embankments of glacier de Tsidjiore Nouve have been formed within the past 4000-5000 years (Röthlisberger and Schneebeli, 1979). The volumes of these embankments have been calculated from cross-profiles located at intervals of $100 \mathrm{~m}$. One problem arises from the fact that the proximal faces are concealed by the glacier, except for a $1 \mathrm{~km}$ section at the lowermost end of the northern embankment, where melt-back of the glacier margin has exposed part of the inner slope (at $30-40^{\circ}$ in angle). It seems reasonable to infer, on a number of grounds, that this exposed face approximates to the former subglacial surface. Therefore, in the calculations of volumes of debris contained within the lateral moraine embankments (Table I)

limits to the steepness of the proximal slopes are assumed to lie within the range from $30^{\circ}$ (minimum) and $45^{\circ}$ (maximum), with the former being more realistic than the latter. It is also assumed that the moraine embankments are not ice-cored; certainly where the moraine has been recently eroded (for example, where sudden flows of melt water from the overriding ice have incised gullies several metres in depth into the distal slope) no ice has been exposed. Nevertheless, other large lateral moraines in this area contain ice cores in their lowermost parts (Smal1, 1983), so that the question must remain to some extent an open one.

As Table IA shows, the gross volume of the embankments lies within the range $(9.2-12.3) \times 10^{6} \mathrm{~m}^{3}$ (with the volume of the northern moraine being approximately

TABLE I. THE NEOGLACIAL MORAINE EMBANKMENTS, GLACIER DE TSIDJIORE NOUVE

A. Estimated volumes of moraine embankments

$$
\text { Gross volumes }\left(\mathrm{m}^{3}\right)
$$

Corrected volumes (Assumed void space 20\%)

$30^{\circ}$ Proximal slope $45^{\circ}$ Proximal slope $30^{\circ}$ Proximal slope $45^{\circ}$ Proximal slope

$\begin{array}{lrlllll}\begin{array}{l}\text { Northern moraine } \\ \text { Southern moraine }\end{array} & 8037600 & 6028200 & 6430200 & 4822560 \\ & 4228 & 3171 & 180 & 3382592 & 2536844 \\ \text { TOTAL } & 12265864 & 9199380 & 9812792 & 7359504\end{array}$

B. Weight of debris in moraine embankments

(Weight in tonnes, assuming rock density $2.7 \mathrm{Mg} / \mathrm{m}^{3}$ )

$$
30^{\circ} \text { Proximal slope } 45^{\circ} \text { Proximal slope }
$$

$\begin{array}{lrrrrr}\text { Northern moraine } & 17361540 & 13020 & 912 \\ \text { Southern moraine } & 9132998 & 6 & 849 & 749\end{array}$

$\begin{array}{lllll}\text { TOTAL } & 26494538 & 19870661\end{array}$

C. Estimated annual rates of accumulation in the Neoglacial period (Weight in tonnes)

Assuming 5000 years accumulation

$30^{\circ}$ Proximal slope $45^{\circ}$ Proximal slope $30^{\circ}$ proximal slope $45^{\circ}$ proximal slope

\begin{tabular}{lrrrr} 
Northern moraine & 3472 & 2604 & 6944 & 5208 \\
Southern moraine & 1826 & 1369 & 3653 & 2739 \\
TOTAL & 5298 & 3973 & 10597 & 7947 \\
\hline
\end{tabular}

Assuming 2500 years accumulation 
twice, that of the southern). The moraine debris is now well packed, owing to the settling of dumped sediments and the washing into voids of fines by melt water. In calculating the corrected volumes a relatively low void space of $20 \%$ has therefore been assumed. This gives a range of moraine volume from $7.4 \times 10^{6} \mathrm{~m}^{3}$ (with proximal slope $45^{\circ}$ ) to $9.8 \times 10^{6} \mathrm{~m}^{3}$ (with proximal slope $\left.30^{\circ}\right)$. Table IB depicts the weight in tonnes of the debris (calculated for purposes of comparison with other sediment outputs from glacier de Tsidjiore Nouve), assuming a rock density of $2.7 \mathrm{Mg} / \mathrm{m}^{3}$. Table IC shows estimated annual rates of debris accumulation by weight. If the accumulation had been constant over the 5000 year period of formation, the annual rate would have lain between 4000 and 5000 tonnes. However, with a known history embracing several Neoglacial advances and retreats, this is unlikely. More realistically, it has been assumed that "permanent" deposition on the distal moraine slopes was taking place during only half this period (up to 2500 years). This suggests that annual accumulation rates were within the range 7950-10 600 tonnes (with the latter more probable than the former).

\section{PRESENT RATES OF MORAINE ACCUMULATION}

At the present time, deposition is occurring at five sites along the lateral moraine embankments of glacier de Tsidjiore Nouve, as well as at the glacier snout. These sites, and their principal characteristics, are as follows (Fig. 3 ).

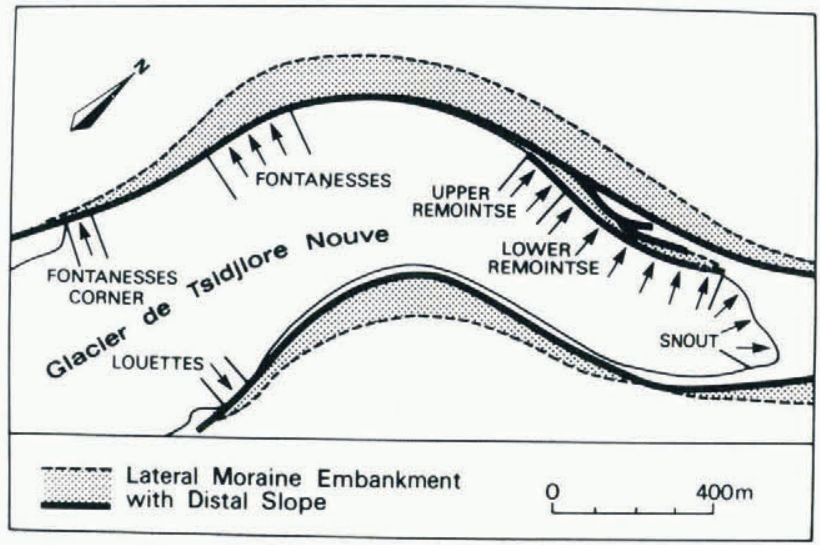

Fig. 3. Sitrs of active deposition by overriding ice, glacier de Toidjiore Nowe, sumer 1982.

(1) Towards the head of the northern moraine (at a site designated for convenience "Fontanesses") the ice margins are overriding the embankment summits over a distance of at least $200 \mathrm{~m}$ (Smal1, 1983). This is a very important site for the deposition of both supraglacial and englacial debris (the latter derived from a discontinuous ice face several metres in height). (2) At the very head of the northern moraine (designated "Fontanesses corner") there is a much shorter section (some $40 \mathrm{~m}$ ) of glacial overriding and deposition of supraglacial debris.

(3) Towards the lower (eastern) end of the northern embankment, recession of the glacier margin has left a valley between the ice face and the proximal slope of the embankment. Deposition is very active along the uppermost $130 \mathrm{~m}$ section (designated "Upper Remointse") of the glacier margin, and is leading to the formation of a new "inner" moraine ridge (Fig. 4). The crests of this ridge are being overridden by the ice in a manner broadly similar to that at "Fontanesses".

(4) Down-glacier from the "Upper Remointse" site, a further section of the glacier margin (designated "Lower Remointse"), some $525 \mathrm{~m}$ in length, comprises

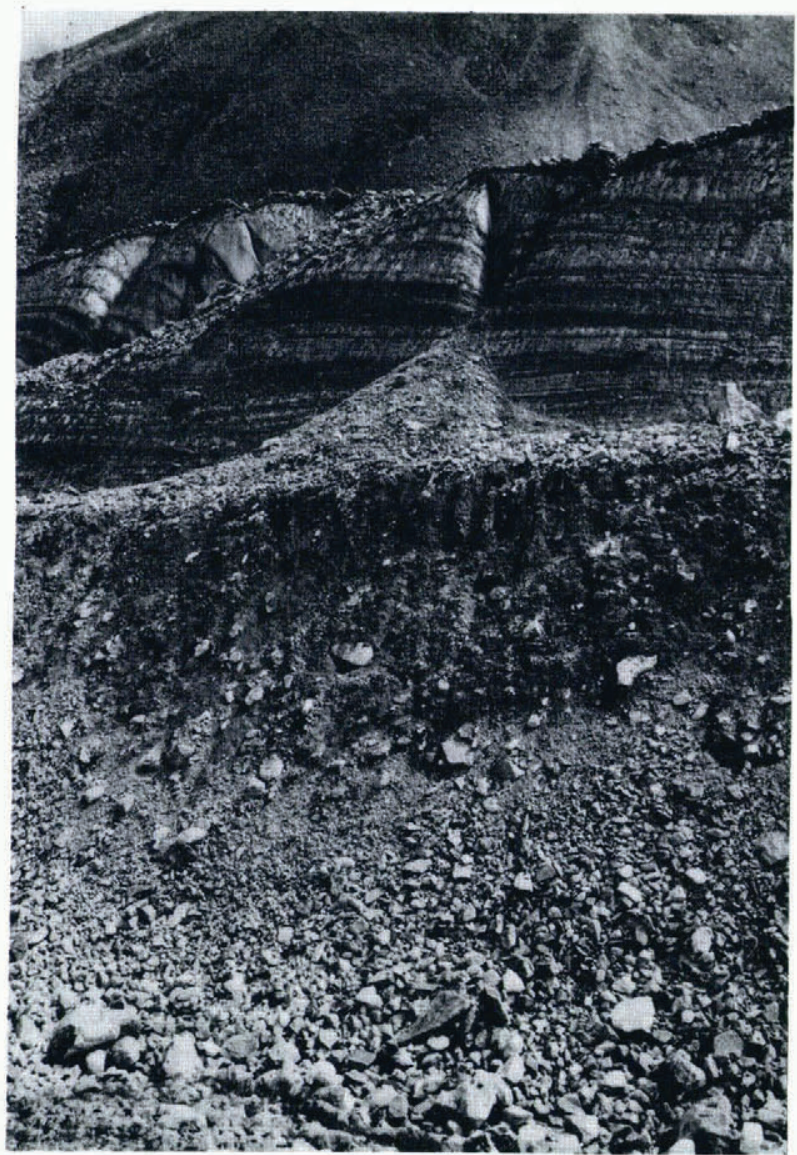

Fig. 4. View of part of the "Upper Remointse" site, August 1982. Note the ice face standing above the lateral moraine, the supraglacial debris being undermined by ice marginal recession, and the debris fan accumulating temporarily on the moraine crest.

a partially overhanging ice face up to $20 \mathrm{~m}$ or more in height. From the crest of this ice slope, supraglacial debris falls and slides almost continuously, though at the base there is no longer a moraine ridge comparable with that at "Upper Remointse". Rather, the deposits accumulate on the proximal siope of an "inner" branch of the lateral moraine embankment. Some debris at the base of this slope is removed by an ice-marginal stress which seasonally develops along the glacier edge.

(5) Towards the head of the southern moraine embankment (at a site designated "Louettes"), the ice margin again overrides the crests over a distance of $40 \mathrm{~m}$, and dumping of supraglacial debris is moderately active.

(6) At the glacier snout (designated "Snout") deposition is very active as the $250 \mathrm{~m}$ long ice face ablates back, undermining the cover of supraglacial debris and releasing englacial sediment. This is a much more complex depositional environment than at sites 1-5. Recent accumulations of debris in the proglacial zone are being overridden and concealed by the advancing glacier. However, towards the southern end of the snout, supraglacial debris in particular is accumulating in large quantities on the lower ice slopes. This debris cover restricts ablation of the underlying ice; at the same time the largely bare upper ice face is melting back relative to the lower slope, with the result that a debris-covered "ice pediment" has formed.

In designing a programme of monitoring sediment accumulation at the margins of glacier de Tsidjiore Nouve, several difficulties need to be surmounted. 
The distal slopes of the lateral moraine are steep and by their nature highly unstable, and there are numerous falls of large boulders and stones from the overriding ice and embankment crests. The hazards of working at the snout (a steep $50 \mathrm{~m}$ ice slope, capped by loose rock fragments) are particularly severe. Survey of moraine profiles by conventional levelling techniques is therefore impracticable. Moreover, attempts to measure moraine accretion by artificial debris traps (such as sheets of heavy-duty plastic placed at points where deposition is most active) achieved limited success. It was therefore decided to use two techniques of measurement, one based on remote sensing of changes in moraine profiles, and the other involving only brief visits to the moraine faces.

\section{A. Photogrametric survey}

Photogrammetry has for long been recognized as a useful aid to glaciological studies. For example, terrestrial photogrammetry was used by Finsterwalder (1931) in measuring glacier flow, and has subsequently been applied by Voigt (1966), Konecny (1964, 1966), and Arnold (1981). Aerial photogrammetry has been employed in mass-balance studies (Morgan, 1973; Dorrer and Wendler, 1976), and to map long-term development of glacial landforms in front of retreating Icelandic glaciers. In order to determine small short-term Stirling (1982) developed a technique for constructing very accurate cross-profiles from ground-based stereo photographs.

The potential application of the latter technique to the measurement of debris accumulation on moraines will be apparent. In the event it was not possible to survey photogrammetrically all the sites at glacier de Tsidjiore Nouve where deposition is occurring. It is essential to establish camera positions along a plane parallel to, and not too far distant from, the moraine slope to be profiled. In addition, the camera positions should be established at similar altitudes at each site. Providing these conditions are met, a high degree of precision in the profile is possible (see the discussion of individual sites below). Unfortunately, suitable camera positions were not available at "Fontanesses corner" and "Lower Remointse"; and serious problems of interpretation arose when the technique was applied at "Snout", for the simple reason that changes in profile reflected not merely deposition but also advances in the glacier itself.

Other requirements of the photogrammetric technique are as follows: A minimum of three coordinated control points should appear on both photographs of the stereo pair. In this study between five and nine points were established at each site. These points (marked by "Dayglo" orange boards or painted markers on embedded boulders) were coordinated with reference to Swiss national triangulation points and traverse points installed during the University of Glasgow survey of 1977 . The present survey was based on a Wild T-1A theodolite and a Precision Internationa 1400-S electro-magnetic distance measurer (E.D.M.). Photographs were taken using a Wild P-32 photogrammetric camera (focal length $64.03 \mathrm{~mm}$ ) on $120 \mathrm{~mm}$ colour transparency film. Camera positions were selected to give good photographic coverage from as close a range as possible, with camera separation at 0.2 to 0.3 times the distance from camera to object. It was not necessary to use exactly the same camera positions for each stereo pair, as camera parameters were recalculated from the control points during analysis on the stereo-comparator, a Zeiss Jena Stecometer connected on line to a Digital PDP-11 V03 microcomputer. The use of this equipment to produce accurate ground-surface profiles is described in detail by Stirling (1982).

At two of the three sites it was not possible to detect significant changes in profile over the summer of 1982 (when a series of stereo pairs was taken at "Fontanesses", "Upper Remointse" and "Louettes"), largely because most debris accumulation on the distal moraine slopes occurs in winter and spring (Fig. 2). It was therefore decided to construct additional profiles from the aerial photographs taken on 15 September 1977, for a survey by Glasgow University. Because of the much greater distance of the camera from the object, potential errors were greater than for the ground-based photogrammetry (approximately $\pm 0.5 \mathrm{~m})$. In practice, the fit of the stereomodel to the control was considerably better than this. Indeed, in areas which had not experienced deposition there was a remarkable coincidence between the 1977 profiles (from aerial photograph) and the 1982 profiles (from ground-based photography), thus increasing confidence in the technique used. For the summer of 1982 it was decided to use only the first and last stereo pairs at each site. Thus each drawn profile comprises three sub-profiles: for September 1977, for July 1982, and for August/September 1982. The findings at individual sites are as follows.

(1) "Fontanesses". Camera positions were established on the hill-slope opposite the distal moraine slope at a range of about $200 \mathrm{~m}$ from the ice margin, allowing construction of profiles with a precision of at least $\pm 0.15 \mathrm{~m}$. The stereo pairs used were taken on 5 July and 9 September. Five profiles (at $50 \mathrm{~m}$ intervals) were drawn along the $200 \mathrm{~m}$ depositional margin. These revealed a consistent pattern of deposition between 1977 and 1982 (though there was little detectable change between July and September 1982). Maximum accumulation has taken place on the upper part of the distal face, though many large individual boulders which have fallen to the slope base could be detected. The mean cross-sectional area of accretion for the profiles has been calculated as $40.69 \mathrm{~m}^{3}\left(8.14 \mathrm{~m}^{3} / \mathrm{a}\right)$. Assuming an even rate of deposition along the

"Fontanesses" margin, a volumetric increase at the site of $8138 \mathrm{~m}^{3}$ over the five year period is implied $\left(1627 \mathrm{~m}^{3} / \mathrm{a}\right)$.

(2) "Louettes". Camera positions were established opposite this site at a maximum range of $80 \mathrm{~m}$, allowing construction of profiles with a precision of \pm $0.07 \mathrm{~m}$. The stereo pairs used were taken on $5 \mathrm{July}$ and 18 August. Six profiles (at 5-10 m intervals) were drawn along the $40 \mathrm{~m}$ depositional margin. Estimation of deposition during the summer of 1982 was difficult; early in the season the lower moraine slopes were masked by snow, and as this gradually melted the visible moraine face was extended downslope. Two aerial stereo pairs from the 1977 survey were available; both were used in profile construction, with slightly differing results. Calculated increments of debris between 1977 and 1982 were $649 \mathrm{~m}^{3}$ and $765 \mathrm{~m}^{3}$; in calculating total deposition on the moraine embankments, the mean $\left(707 \mathrm{~m}^{3}\right)$ was taken $\left(141 \mathrm{~m}^{3} / \mathrm{a}\right)$.

(3) "Upper Remointse" (Fig. 5) Camera positions were established, opposite this highly active face, on the crest of the main moraine embankment at a distance of only $20-40 \mathrm{~m}$, allowing construction of profiles with a precision of $\pm 0.02 \mathrm{~m}$. Control points were difficult to maintain, owing to numerous boulder falls, but three targets remained throughout the summer of 1982 . Three profiles (at $5 \mathrm{~m}$ intervals) were drawn; these showed near-uniform accumulation over the period 1977-82, and considerable deposition (to a depth of more than a metre in places) between 12 July and 9 September 1982 (the dates of the stereo pairs used). Calculations revealed a total accumulation (1977-82) of $204 \mathrm{~m}^{3}$ over the $10 \mathrm{~m}$ face bounded by the outside profiles. A similar rate of deposition is evidently occurring over the $130 \mathrm{~m}$ section of the ice margin at "Upper Remointse", suggesting a total accumulation of $2654 \mathrm{~m}^{3}\left(530 \mathrm{~m}^{3} / \mathrm{a}\right)$.

\section{B. Measurement of ice marginal recession}

At sites where photogrammetric survey was impossible, an alternative technique for measuring depos- 


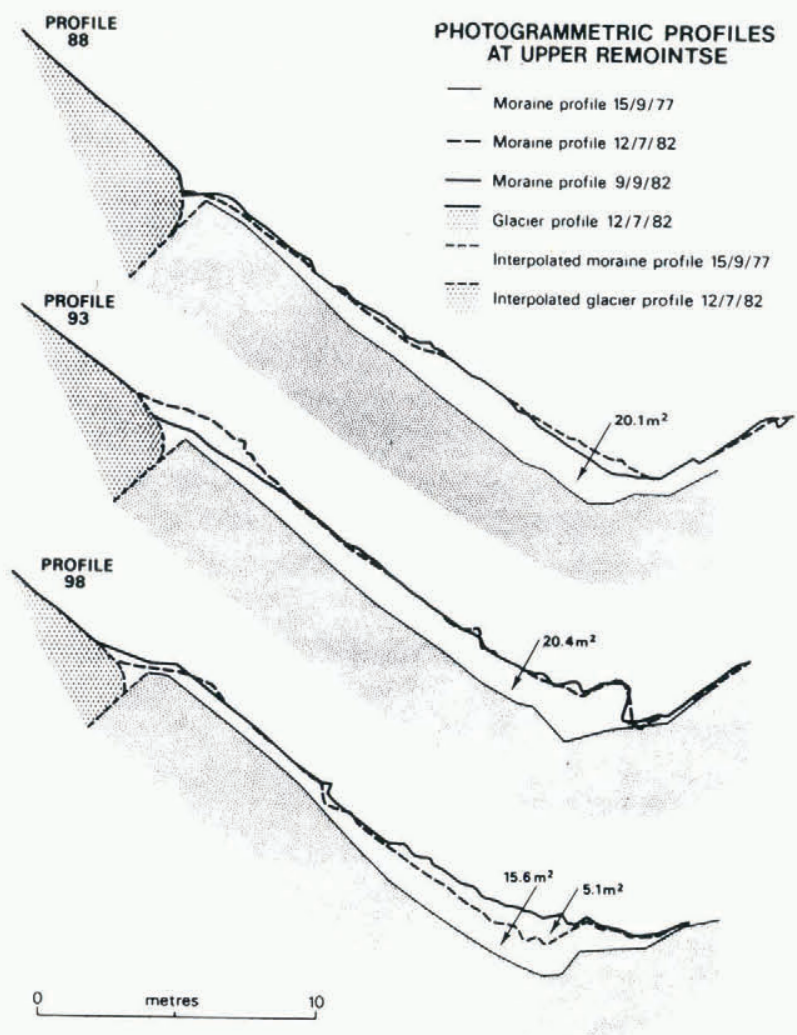

Fig. 5. Moraine profiles at "Upper Remointse". (Similar profiles, constructed photogrammetrically, for the "Fontanesses" and "Louettes" sites were used for the oalculations of annual moraine accumulation in Table

ition was necessary. An obvious approach was to measure ( $i$ ) the ablation rate of the glacier margin, and $(i i)$ the thickness of the supraglacial debris layer being undermined by the ice-marginal recession. During August and early September 1982 a series of ablation recordings, from bamboo canes drilled into suitable ice exposures, was made at four sites (chosen to represent different aspects and altitudes).

(a) At "Fontanesses" mean diurnal melt-back of the ice margin, over the period 14 August to 9 September, ranged from 2.77 to $3.65 \mathrm{~cm} / \mathrm{d}$.

(b) At "Upper Remointse" mean diurnal melt-back, over the period 21 to 26 August, ranged from 3.06 to 3.56 $\mathrm{cm} / \mathrm{d}$.

(c) At "Lower Remointse" mean diurnal melt-back, over the period 21 August to 9 September, ranged from 1.74 to $1.79 \mathrm{~cm} / \mathrm{d}$.

(d) At "Snout" (where only one cane survived the frequent boulder falls) the measured ablation rate between 21 and 28 August was $2.71 \mathrm{~cm} / \mathrm{d}$.

If these values are representative (and they were obtained during a period of varied weather, embracing snow, rain, and hot sunny days), it would appear that on average the exposed margins of glacier de Tsidjiore Nouve melt back at about $3 \mathrm{~cm} / \mathrm{d}$ (except at "Lower Remointse", where the sheltered northerly aspect results in a reduced rate of $1.8 \mathrm{~cm} / \mathrm{d}$ ). Since the ablation season here lasts approximately $170 \mathrm{~d}$ on average, the total marginal recession is in the order of $5 \mathrm{~m} / \mathrm{a}$ (or $3 \mathrm{~m} / \mathrm{a}$ at "Lower Remointse"). Measurements of supraglacial debris at 41 sites around the glacier periphery have revealed a mean thickness of $0.8 \mathrm{~m}$. From this it would appear that (except at "Lower Remointse") the rate of deposition of supraglacial debris is in the order of $4 \mathrm{~m}^{3}$ per metre of glacier margin each year. This amount would be increased by the melting out of englacial debris bands (which can sometimes be clearly observed, as at "Fontanesses", but at other sites are hidden by a veneer of slipped supraglacial debris). It is interesting to note that at "Fontanesses" the annual increment to the moraine embankment (as shown by photogrammetry) between 1977 and 1982 was $8.14 \mathrm{~m}^{3}$ per metre of glacier margin, thus implying equal contributions from supraglacial and englacial debris sources. At "Upper Remointse", on the other hand, the annual increment (shown by photogrammetry) over the period was $4.08 \mathrm{~m}^{3}$ per metre of glacier margin. This implies no contribution from englacial debris sources, though in fact some englacial bands are exposed here and must release a certain amount of debris to the moraine.

In estimating rates of sedimentation at "Fontanesses corner", "Lower Remointse", and "Snout", those determined by photogrammetry at "Fontanesses", "Upper Remointse", and "Louettes" have been taken into account, but modifications dependent on the details of each site and the measurements of ablation of the glacier margin have been made to these.

(1) "Fontanesses corner". The mechanism of deposition is similar to that at "Fontanesses" (though more limited ice exposures may restrict the output of englacial debris), but the site is virtually a "mirror image" of that at "Louettes", being at the very head of the northern moraine embankment. If the rate of sediment output were comparable with that at "Fontanesses", total deposition over the $40 \mathrm{~m}$ margin would be $325 \mathrm{~m}^{3} / \mathrm{a}$; if it were comparable with "Louettes" the annual output would be only $141 \mathrm{~m}^{3}$. Most probably the true figure lies nearer the latter than the former. (2) "Lower Remointse". This site is in several respects a natural continuation of "Upper Remointse", though, as the north-facing ice margin increases in height, ablation appears to be reduced (by some $40 \%$ by comparison with that measured at other sites). It is therefore assumed that the annual debris output at

"Lower Remointse" should be reduced to $2.45 \mathrm{~m}^{3}$ per metre of ice margin from the $4.08 \mathrm{~m}^{3}$ measured at "Upper Remointse". Over the total $525 \mathrm{~m}$ ice margin at "Lower Remointse", this would give an annual deposition rate of $1286 \mathrm{~m}^{3}$.

(3) "Snout". The ice exposure here is some $250 \mathrm{~m}$ in length. Overall supraglacial debris thickness (though somewhat greater towards the southern end of the snout) is comparable with that at other marginal sites. Estimates of annual rates of deposition, based on maximum and minimum rates for other marginal sites ("Fontanesses" and "Louettes") lie between 2034 and $884 \mathrm{~m}^{3}$. Most probably the true figure is closer to the former than the latter, particularly in view of the relatively large amounts of englacial debris released from the high snout face.

\section{CONCLUSIONS}

Table II shows the calculated rates of annual accumulation of debris along the margins of glacier de Tsidjiore Nouve. For purposes of comparison with other forms of sediment output (see below), the volumes of debris have been converted into weight (tonnes), assuming a rock density of $2.7 \mathrm{Mg} / \mathrm{m}^{3}$ and a void space of $30 \%$ (since these deposits are as yet unpacked, by comparison with the older moraine sediments). The calculated deposition on the lateral moraine embankments includes two components: 4347 tonnes/a at sites surveyed photogrammetrically ("Fontanesses", "Upper Remointse", "Louettes"); and between 2698 and 3046 tonnes/a at other sites ("Fontanesses corner", "Lower Remointse"). The annual deposition occurring at present on the lateral moraines (between 7045 and 7354 tonnes) is thus well in line with deposition rates for the Neoglacial period (between 7950 and 10600 tonnes). To these figures must be added the estimated annual deposition at the glacier snout (between 1671 and 3845 tonnes). The 
TABLE II. ESTIMATED RATES OF ANNUAL MARGINAL ACCUMULATION, GLACIER DE TSIDJIORE NOUVE

\begin{tabular}{|c|c|c|c|c|}
\hline $\operatorname{Mar}$ & ${ }_{\mathrm{m}}$ length & $\begin{array}{l}\text { Annual accumulation } \\
\mathrm{m}^{3} / \mathrm{m} \text { of glacier margin }\end{array}$ & Annual accumulation at site & $\begin{array}{c}\text { Annual accumulation at } \\
\text { tonnes }\end{array}$ \\
\hline 1 "Fontanesses" & 200 & 8.14 & 1627 & 3076 \\
\hline 2 "Fontanesses corner & 40 & $3.54-8.14$ & $141-325$ & $267-615$ \\
\hline 3 "Upper Remointse" & 130 & 4.08 & 530 & 1003 \\
\hline 4 "Lower Remointse" & 525 & 2.45 & 1286 & 2431 \\
\hline 5 "Louettes" & 40 & 3.54 & 141 & 267 \\
\hline 6 "Snout" & 250 & $3.54-8.14$ & $884-2034$ & $1671-3845$ \\
\hline Total & - & - & $4611-5946$ & $8716-11238$ \\
\hline
\end{tabular}

TABLE III. ESTIMATES ANNUAL RATES OF DEPOSITION/TRANSPORT, GLACIER DE TSIDJIORE NOUVE

(1) Direct deposition

(a) Deposition of supraglacial and englacial debris on lateral moraines

(b) Deposition of supraglacial and englacial debris at snout

(2) Proglacial stream transport
(c) Suspended sediment in pro-glacial streams
(d) Bed-load in pro-glacial

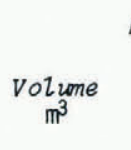

Maximum

2738

1424

3845

14.9

619

1671

9.6

\begin{tabular}{lrrrrrr}
3515 & 9491 & 37.0 & 3223 & 8702 & 50.0 \\
$\frac{1835}{9512}$ & $\frac{4955}{625}$ & $\frac{19.3}{100.0}$ & & nil & nil & $\underline{6451}$ \\
\hline & & & & 17 & 418 & 100.0 \\
\hline
\end{tabular}

Assuming that bed-load comprises wholly supraglacial and englacial debris deposited at snout (b).

total marginal sediment output of glacier de Tsidjiore Nouve, as determined by the methods outlined in this paper, thus lies within the range 8727 to 11238 tonnes/a (3228 to $\left.4162 \mathrm{~m}^{3}\right)$. This debris appears to be derived mainly from supraglacial and enqlacial sourres. Since the catchment of the glacter covers $4.15 \mathrm{~km}^{2}$, the rate of "erosion" needed to supply the marginai deposits is in the order of 0.78 to $1.0 \mathrm{~mm} / \mathrm{a}$.

However, sediment is also released from glacier de Tsidjiore Nouve by way of melt-water streams from the snout. Detailed studies by I.R. Beecroft, based on one-hourly or four-hourly sampling of suspended sediment in the main pro-glacial stream during the summer of 1981 and 1982, have revealed total outputs of 9491 and 8702 tonnes respectively (3515 and $3223 \mathrm{~m}^{3}$ ). Estimates of bed-load (from sediment traps in a water intake constructed by Grande Dixence S.A.) for these two summers were 4955 and 3005 tonnes

$\left(1835\right.$ and $\left.1113 \mathrm{~m}^{3}\right)$. However, it must be pointed out that a substantial proportion (and possibly most) of the bed-load consists of supraglacial and englacial debris from the glacier snout, so that there is an overlap between marginal sedimentation and bedload.

From data such as these a preliminary interpretation of total sediment output from glacier de
Tsidjiore Nouve can be attempted (Table III). These figures, ranging from 17418 to 25684 tonnes/a, can be taken to imply a total erosion rate in the catchment of the glacier of 1.55 to $2.29 \mathrm{~mm} / \mathrm{a}$. They also add support to the impression, gained subjectively in the field from the extensive supraglacial debris cover, the numerous englacial debris bands, and the massive moraine embankments, that this is geomorphologically an intensely active glacier.

\section{REFERENCES}

Arnold, K.C. 1981. Glaciology, No. 2. Ice ablation measured by stakes and terrestrial photogrammetry - a comparison on the lower part of the White Glacier, Axel Heiberg Island, Canadian Arctic Archipelago. Axel Heiberg Island Research Reports, McGill University, Montreal.(NHRI Paper No. 19.)

Dorrer, E., and Wendler, G. 1976. Climatological and photogrammetric speculations on mass-balance changes of McCall Glacier, Brooks Range, Alaska. Jaurnal of Glaciology, Vol. 17, No. 77, p. 479-90. 
Finsterwalder, R. 1931. Geschwindigkeitsmessungen an Gletschern mittels Photogrammetrie. Zeitschrift fïr Gletscherkunde, Bd. 19, Ht. 4-5, p. 251- 62 .

Konecny, G. 1964. Glacial surveys of Western Canada Photogrammetric Engineering, Vol. 30 , No. 1, p. 64-82. Konecny, G. 1966. Applications of photogrammetry to surveys of glaciers in Canada and Alaska. Canadian Jownal of Earth Sciences, Vol. 3, No. 6, p. 783-98. Morgan, P.J. 1973. A photogrammetric survey of Hoseason Glacier, Kemp Coast, Antarctica. Jovenal of Glaciology, Vol. 12, No. 64, p. 113-20.

Röthlisberger, F., and Schneebeli, W. 1979. Genesis of lateral moraine complexes, demonstrated by fossil soils and trunks: indicators of proglacial climatic fluctuations. (In Schlüchter, C., ed. Proceedings of an INQUA symposium on genesis and lithology of
Quaternary deposits, Zïrich, 10-20 September 1978. Moraines and varves: origin, genesis, classification. Rotterdam, A.A. Balkema, p. 387-419.)

Small, R.J. 1983. Lateral moraines of glacier de Tsidjiore Nouve: form, development, and implications. Jovenal of Glaciology, Vol. 29, №. 102, p. 250-59.

Stirling, D.M. 1982. Measuring short term glacial fluctuations by aerial and terrestrial photogrammetry a comparative study. International Archives of Photogrammetry, Vol. 24, Pt. 5, p. 484-96.

Voigt, U. 1966. The determination of the direction of movement on glacier surfaces by terrestrial photogrammetry. Jovenal of Glaciology, Vol. 6, №. 45, p. 359-67.

Whalley, W.B. 1973. An exposure of ice on the distal side of a lateral moraine. Journal of Glaciology, Vol. 12 , No. 65 , p. 327-29. [Letter.]

MS. received 17 october 1983 and in revised form 12 March 1984 